\title{
STRATEGI MASJID CHENG HO DALAM MENINGKATKAN PENDIDIKAN KEAGAMAAN MUSLIM TIONGHOA DI SURABAYA DAN JEMBER
}

\author{
${ }^{1}$ Muhammad Ali Ridho, ${ }^{2}$ Ahmad Marzuki \\ 12aliridho@gmail.com, ${ }^{2}$ ahmadmarzuki@yudharta.ac.id \\ Universitas Yudharta Pasuruan
}

\begin{abstract}
Everyone in the territory of the Indoneia state is entitled to a religious education to improve its religious education. Therefore, the Government set rules in the Government regulation of the Republic of Indonesia No. 55 year 2007 article 4 paragraph 2 of religious and religious education reads "Every student in the education unit in all lines, levels, and types of education Entitled to a religious education in accordance with the religion he and taught by a religious educator "explains the equality of rights in obtaining religious education at the basic, intermediate and so on. But the fact that the field says, the minority people like ethnic Chinese have difficulty in improving its religious education. The strategy of Cheng Ho Mosque in improving Chinese Muslim religious education.
\end{abstract}

Abstrak : Semua orang yang berada di wilayah Negara Indoneia ini berhak mendapatkan pendidikan agama untuk meningkatkan Pendidikan Keagamaannya. Untuk itu pemerintah menetapkan aturan dalam Peraturan Pemerintah Republik Indonesia No.55 Tahun 2007 Pasal 4 ayat 2 tentang Pendidikan Agama dan Keagamaan berbunyi "Setiap peserta didik pada satuan pendidikan di semua jalur, jenjang, dan jenis pendidikan berhak mendapat pendidikan agama sesuai agama yang dianutnya dan diajar oleh pendidik yang seagama" menjelaskan tentang persamaan hak dalam memperoleh pendidikan agama baik di tingkat dasar, menengah dan seterusnya. Akan tetapi fakta dilapangan mengatakan lain, masyarakat minoritas seperti etnis Tionghoa 
Strategi Masjid Cheng Ho Dalam Meningkatkan Pendidikan Keagamaan Muslim Tionghoa di Surabaya dan Jember

memiliki kesulitan dalam meningkatkan pendidikan keagamaannya. Strategi Masjid Cheng Ho dalam Meningkatkan Pendidikan Keagamaan Muslim Tionghoa.

Kata Kunci : Masjid Cheng Ho, Pendidikan Keagamaan, Muslim Tionghoa

\section{PENDAHULUAN}

Harus kita pahami bahwa Masjid merupakan bangunan yang sangat penting bagi orang ialam. Untuk itu ketika Rasululloh hijrah ke Madinah, Masjid adalah bangunan pertama yang beliau bangun. ${ }^{1}$. Selain sebagai tempat ibadah untuk mendekatkan diri kepada Allah SWT, Masjid pun mempunyai aneka ragam fungsi, antara lain merupakan sarana sentral dakwah, pendidikan (tarbiyah), pengetahuan ilmiah yang komplit dengan perpustakaannya, pusat berkumpulnya umat Islam dalam bermusyawarah dan mengimplementasikan ajaran persatuan, persamaan dan persaudaraan. Singkat cerita, masjid adalah pusat berbagai kegiatan ibadah umat Islam yang mencakup semua bidang aspek kehidupan. Yaitu sebagai pusat kegiatan dan informasi berbagai masalah kaum muslimin, baik terkait pendidikan atau ekonomi sosial. Masjid yang dijadikan Lembaga Pendidikan kaum Muslimin untuk pertama kalinya setelah Nabi Muhammad SAW hijrah. ${ }^{2}$

Kemudian Kyai-Kyai pesantren di Indonesia melanjutkan adat tersebut untuk menggunakan Masjid sebagai sentral pendidikan. ${ }^{3}$ Walaupun saat ini pesantren telah beberapa tempat belajar untuk proses

\footnotetext{
${ }^{1}$ Hasan, M.T. Dinamika Kehidupan Religius. (Jakarta: Listafariska Putra.2000)

2 Nata Abuddin. Sejarah Pendidikan Islam. (Jakarta:Fakultas Ilmu Tarbiyah dan Keguruan.2010)

${ }^{3}$ Ada lima unsur dasar dalam setiap pesantren yaitu : Asrama, Masjid, santri, kitab kuning, dan figur Kyai. Masjid merupakan tempat proses pembelajaran keagamaan yang sangat penting bagi santri. Demikian juga masjid cheng ho yang menjadi salah satu lembaga yang dapat meningkatkan pendidikan keagamaan bagi muslim keturunan tionghoa. Lihat zamakhsari dhofier.....
} 
berlangsungnya kegiatan belajar mengajar, akan tetapi Masjid masih difungsikan sebagai tempat belajar. ${ }^{4}$ Di Masjid tersebut seorang Kyai mengajarkan kitab kuning kepada peserta didiknya (santri) atau pun orangorang sekitar pesantren yang ingin mendapatkan Pendidikan Agama.

Semua orang yang berada di wilayah Negara Indoneia ini berhak mendapatkan pendidikan agama untuk meningkatkan Pendidikan Keagamaannya. ${ }^{5}$ Fakta dilapangan yang sering kita jumpai mengatakan lain, suku/etnis minoritas masih sulit mendapatkan Pendidikan Agama seperti sekolah yang mayoritas agama A kurang menyediakan layanan pada peserta didiknya yang beragama B karena minoritas. terlebih lagi kalau peserta didik tersebut dalam agama adalah minoritas dan dalam suku juga minoritas. ${ }^{6}$ Salah satu etnis minoritas di Indonesia ini adalah etnis Tionghoa. Etnis Tionghoa yang memeluk Agama Islam (Muslim Tionghoa) juga berhak mendapatkan Pendidikan Keagamaan yang layak seperti halnya etnis/suku lainnya. Namun sedikit sekali dan bahkan hampir tidak ada Muslim Tionghoa yang menempuh Pendidikan Keagamaan Islam pada Lembaga Pendidikan Islam formal, bahkan di pondok pesantren modern atau pondok pesantren salaf juga tidak ada Muslim Tionghoa yang belajar disana ${ }^{7}$.

Di Jember Muslim Tionghoa juga sanggat kekurangan sekali Pendidikan Keagamaan. Masyarakat Muslim Tionghoa di Jember sering mengikuti pengajian-pengajian yang dilaksanakan di Masjid-Masjid didaerah sana sebagai upaya untuk meningkatkan Pendidikan Keagamaan mereka ${ }^{8}$.Sebagai orang yang beragama, sudah merupakan sebuah kewajiban untuk mempelajari lebih dalam tentang ajaran agamanya.

4 Daulay, H.P. Sejarah Pertumbuhan dan Pembaruan Pendidikan Islam Di Indonesia. (Jakarta: Kencana.2017)

${ }^{5}$ PP Nomor 55 Tahun 2007 tentang Pendidikan Agama dan Pendidikan Keagamaan

6 (W.2.22/12/18.PA) Wawancara pribadi dengan Andreas salah satu peserta didik non muslim di sekolah menengah atas 22 Desember 2018.

${ }^{7}$ (W.S.2.20/8/18.MTJ) Wawancara dengan Ainun Najib warga Surabaya, 20 Agustus 2018

${ }^{8}$ (W.J.1.7/9/18.MTJ )Wawancara dengan Riyadul Ulum warga Jember, 7 September 2018 
58 ... Potret Masyarakat Multikultural di Indonesia

Strategi Masjid Cheng Ho Dalam Meningkatkan Pendidikan Keagamaan Muslim Tionghoa di Surabaya dan Jember

Muslim Tionghoa tersebut memperdalam Pendidikan Keagamaan lewat majlis taklim yang ada di Masjid. Kemungkinan ada sebuah Masjid tertentu yang dijadikan sebagai tempat majlis taklim bagi Muslim Tionghoa untuk meningkatkan Pendidikan Keagamaan Islamnya. Masjid tersebut adalah Masjid Cheng Ho yang didirikan oleh Muslim Tionghoa dan tersebar di beberapa wilayah Indonesia. Masjid Cheng Ho yang. Terletak di Kota Surabaya dan Jember adalah Masjid Cheng Ho yang sudah melaksanakan Pendidikan keagamaan.

\section{PEMBAHASAN}

\section{STRATEGI MASJID CHENG HO DALAM MENINGKATKAN PENDIDIKAN KEAGAMAAN MUSLIM TIONGHOA}

Untuk meningkatkan Pendidikan Keagamaan Muslim Tionghoa, Masjid Cheng Ho memiliki sebuah strategi yaiutu menjalankan beberapa program pendidikan keagamaan yang terjadwal dan rutin dijalankan. Program-program tersebut diajarkan oleh pendidik-pendidik yang berkompeten yang sengaja didatangkan oleh Masjid Cheng Ho untuk meningkatkan pendidikan keagamaan Muslim Tionghoa. Programprogram pendidikan keagamaan yang dijalankan Masjid Cheng Ho diantaranya adalah : Pendidikan Al-Qur'an, Pendidikan Hadist, Pendidikan Akidah dan Pendidikan Akhlaq.

\section{a. Pendidikan Al-Qur'an}

Al-Qur'an yang secara harfiah berarti "bacaan sempurna" merupakan suatu nama pilihan Allah yang sungguh tepat, karena tiada suatu bacaan pun sejak manusia mengenal tulis-baca lima ribu tahun yang lalu yang dapat menandingi Al-Qur`an, bacaan sempurna lagi mulia itu. Tiada bacaan semacam Al-Qur’an yang dibaca oleh ratusan juta ribu orang yang tidak mengerti artinya dan atau tidak dapat menulis dengan aksaranya. Bahkan dihafal huruf demi huruf oleh 
orang dewasa, remaja dan anak-anak. Tiada bacaan melebihi AlQur`an dalam perhatian yang diperolehnya, bukan saja sejarahnya secara umum, tetapi ayat demi ayat, baik dari segi masa, musim, dan saat turunnya, sampai kepada sebab-sebab serta waktu turunnya.

Al-Qur`an yang dalam benak kaum muslimin sepanjang hayat sebagai kalam Allah, yang diyaii sebagai "petunjuk bagi manusia" dan memberikan "peneranganan atas segala sesuatu" sehingga tidak ada sesuatu pun yang ada dalam kehidupan nyata yang luput dari penjelasannya. Bila diasumsikan bahwa kandungan Al-Qur’an bersifat universal, berarti aktualitas makna tersebut pada tataran kesejarahan meniscayakan dialog dengan pengalaman manusia dalam konteks waktu. Hal ini juga berlaku dengan kajian tafsir yang ada pada Al-Qur`an.

Tafsir sebagai usaha memahami dan menerangkan maksud dan kandungan ayat-ayat suci Al-Qur’an telah mengalami perkembangan yang cukup bervariasi, sebagai hasil karya umat manusia (umat Islam). Terjadinya keanekaragaman dalam corak penafsiran adalah hal yang tak terhindarkan. Berbagai faktor dapat menimbulkan keberagaman ini, misalnya perbedaan kecenderungan, interest, motivasi mufassir (mufassir adalah orang yang memberi tafsiran, komentar atau penjelasan ${ }^{9}$ ), perbedaan misi yang diemban, perbedaan kedalaman dan ragam ilmu yang dikuasai, perbedaan masa dan lingkungan yang mengitari, perbedaan situasi, dan lain sebagainya.

Dalam konteks pendidikan dalam Al-Qur`an, Nabi dijadikan sebagai figur ideal seorang pendidik yang telah membuktikan dirinya sebagai orang yang mampu merubah perilaku individu-individu bahkan umat yang terkenal memiliki sifat, karakter dan budaya yang keras dan kasar. Nabi membimbing mereka menjadi pribadi-pribadi

${ }^{9}$ Kamus Al-Munawwir dari A.W. Munawwir edisi kedua cetakan ke 25 tahun 2002, hal. 1055. 
Strategi Masjid Cheng Ho Dalam Meningkatkan Pendidikan Keagamaan Muslim Tionghoa di Surabaya dan Jember

yang shaleh, cerdas, berani dan sejumlah sifat-sifat yang terpuji lainnya, bahkan pribadi-pribadi itu melahirkan budaya yang tinggi dan beradab. Dalam pandangan pendidikan upaya Nabi tersebut dikatakan sebagai suatu upaya tindakan nyata penerapan metode pendidikan yang tepat dan sesuai dengan sasaran pendidikannya, bukan suatu yang hanya kebetulan, melainkan suatu tindakan yang disengaja dan berlandaskan kepada suatu pandangan yang benar tentang manusia dan nilai-nilai yang diyakininya. Menetapkan Nabi sebagai figur ideal bukan hanya pandangan muslim melainkan ditunjukkan Allah sendiri melalui firmannya:

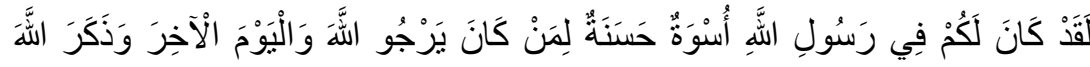
كَثِيرً

Artinya :"Sungguh, telah ada pada (diri) Rasulullah itu suri teladan yang baik bagimu (yaitu) bagi orang yang mengharap (rahmat) Allah dan (kedatangan) hari Kiamat dan yang banyak mengingat Allah". Surat Al-Ahzab 21. ${ }^{10}$

Pendidikan merupakan upaya yang dilakukan oleh manusia dan untuk manusia dengan berbagai perangkat, karakter dan eksistensinya. Sedangkan Al-Qur'an merupakan firman Allah yang selanjutnya dijadikan pedoman hidup (way of life) kaum muslim yang tidak ada lagi keraguan di dalamnya. Di dalamnya terkandung ajaran-ajaran pokok (prinsip dasar) menyangkut segala aspek kehidupan manusia yang selanjutnya dapat dikembangkan sesuai dengan nalar masingmasing. 11

Pendidikan Al-Qur'an yang dijalankan Masjid Cheng Ho Surabaya adalah dengan cara mengadakan pengajian tafsir rutin untuk

\footnotetext{
${ }^{10}$ Agama, D. (2010). Alquran dan Terjemahannya. Jakarta: Lajnah Pentashih Alquran.

${ }^{11}$ Tabrani, Z. A. Menelusuri Metode Pendidikan dalam Al-Quran dengan Pendekatan Tafsir Maudhui. (Serambi Tarbawi, 2(1).2014)
} 
masyarakat umum. ${ }^{12}$ Sedangkan Masjid Cheng Ho Jember menjalankan pendidikan Al-Qur'an dengan beberapa cara diantaranya : Mengaji Al-Qur'an anak usia SD, Mengaji Al-Qur'an untuk dewasa, Pendidikan Qur'an dan Tafsir dalam kegiatan Kajian Muallaf. Adapun kajian Tafsir untuk masyarakat yang ingin memperdalam pendidikan keagamaannya. ${ }^{13}$

\section{b. Pendidikan Hadist}

Hadits menurut bahasa artinya baru. Hadits juga secara bahasa-berarti "sesuatu yang dibicarakan dan dinukil", juga "sesuatu yang sedikit dan banyak". Bentuk jamaknya adalah ahadits. Sedangkan Hadits menurut istilah ahli hadits adalah Apa yang disandarkan kepada Nabi Shallallahu Alaihi wa Sallam, baik berupa ucapan, perbuatan, penetapan, sifat, atau sirah beliau, baik sebelum kenabian atau sesudahnya. Sedangkan menurut ahli ushul fikih, hadits adalah perkataan, perbuatan, dan penetapan yang disandarkan kepada Rasulullah Shallallahu Alaihi wa Sallam setelah kenabian. Adapun sebelum kenabian tidak dianggap sebagai hadits, karena yang dimaksud dengan hadits adalah mengerjakan apa yang menjadi konsekwensinya. Dan ini tidak dapat dilakukan kecuali dengan apa yang terjadi setelah kenabian. ${ }^{14}$

Adapun pendidikan hadist yang dijalankan Masjid Cheng Ho Surabaya dan Jember bersamaan dengan pendidikan lain seperti pendidikan tasawuf, pendidikan Aqidah dan pendidikan akhlaq. Pendidikan hadist untuk menunjang pendidikan tersebut agar memiliki contoh dari apa yang dilakukan nabi sesuai dengan dalil yang jelas.

\footnotetext{
${ }^{12}$ Wawancara dengan Ust. Hariyono Ong selaku Ketua Takmir Masjid Cheng Ho Surabaya pada Hari Senin, 20 Mei 2019

${ }^{13}$ Wawancara dengan Ust. Oei Cin Hai (Ust. Nasrulloh) Selaku Ketua bidang dakwah PITI Jember Pada Hari Rabu, 15 Mei 2019

${ }^{14}$ Al-Qaththan, S. M. Pengantar Studi Ilmu Hadits. (Pustaka Al Kautsar.2014) H 18-22
} 


\section{c. Pendidikan Akidah}

Aqidah merupakan asas kehidupan manusia. Setiap insan yang lahir ke dunia ini sudah dibekalkan dengan fitrah beraqidah dan keyakinan yang menjadi pegangan hidup. Mereka akan mempertahankan kepercayaan dan pegangan tersebut walaupun terpaksa membayar dengan harga yang mahal, sehingga sanggup mengorbankan jiwa dan harta. Dalam Islam kepercayaan ini dikenali sebagai aqidah. Justeru itu setiap insan akan melakukan tindakan dan aktiviti mereka selaras dengan kepercayaan dan pegangan aqidah masing-masing. Islam telah meletakkan aqidah di tempat yang paling utama di dalam kehidupan. Tanpa aqidah yang benar semua amalan tidak akan diterima dan sia-sia belaka.

Mentauhidkan Allah merupakan aqidah yang dibawa oleh semua nabi dan rasul. Setiap rasul menyeru umat masing-masing supaya beriman kepada Allah dan mentauhidkanNya. Cara dan pendekatan yang digunakan oleh para rasul mudah dipahami. Kerana itu orang yang menerima dakwah dan ajakan mereka menerimanya dengan jelas, sementara yang menolaknya, mereka menolaknya dengan jelas juga. Untuk beriman kepada Allah dengan sebenarnya perlu mengenaliNya melalui wahyu, sama ada dari al-Qur'an ataupun al-hadith. Al-Qur'an dan al-hadith telah menggambarkan kepada manusia seluruhnya tentang Allah dengan jelas dan sempurna. Dengan gambaran keagungan Allah melalui nama-nama dan sifat-sifatNya itu memberi kefahaman kepada hambaNya tentang kehebatan dan keagungan Allah. 
Dengan itu mereka dapat mengenaliNya lantas beriman dan mentauhidkan Allah dengan sebenar-benarnya. ${ }^{15}$

Pendidikan Akidah dilaksanakan Masjid Cheng Ho Surabaya dan Jember meliputi : 1. pembinaan muallaf dengan jadwal yang tidak tersusun karena tidak bisa menentukan kapan orang muallaf akan ada. 2. Tauhid untuk mengenalkan Muslim Tionghoa kepada sang pencipta. Dan 3. Fiqih Ibadah sebagai jalan untuk meng hubungkan seserang dengan sang pencipta.

\section{d. Pendidikan Akhlaq}

Pengertian akhlak atau moral adalah sebuah sistem yang lengkap yang terdiri dari karakteristik-karakteristik akal atau tingkah laku yang membuat seseorang menjadi istimewa. Karakteristikkarakteristik ini membentuk kerangka psikologi seseorang dan membuatnya berperilaku sesuai dengan dirinya dan nilai yang cocok dengan dirinya dalam kondisi yang berbeda-beda. Pengertian akhlak menurut Imam Abu Hamid al-Ghazali bahwa yang dimaksud akhlak atau al-khuluq adalah merupakan sifat yang terpatri dalam jiwa, yang darinya terlahir perbuatan-perbuatan dengan mudah tanpa memikirkan dan merenung terlebih dahulu. Jika sifat yang tertanam itu darinya terlahir perbuatan baik dan terpuji menurut rasio dan syariat maka sifat tersebut dinamakan akhlak yang baik. Jika yang terlahir adalah perbuatan buruk maka sifat tersebut dinamakan dengan ahklak yang buruk. $^{16}$

${ }^{15}$ Mat, J. Karya-Karya Aqidah Islam: Satu Tinjauan Ringkas Terhadap Penulisannya Sepanjang Zaman. (Jurnal Usuluddin, 8,1998) 21-40.

${ }^{16}$ Semiawan, Conny. Perspektif Pendidikan Anak Berbakat, (Jakarta, PT Gramedia.1997) 
64 :.: Potret Masyarakat Multikultural di Indonesia

Strategi Masjid Cheng Ho Dalam Meningkatkan Pendidikan Keagamaan Muslim Tionghoa di Surabaya dan Jember

Sedangkan menurut Ahmad bin Musthafa akhlak didefinisikan sebagi ilmu yang darinya dapat diketahui jenis-jenis keutamaan. Keutamaan itu adalah terwujudnya keseimbangan antara tiga kekuatan, yaitu kekuatan berpikir, kekuatan marah, dan kekuatan syahwat. Lebih lanjut, akhlak atau moral mempunyai empat makna yaitu 1) moral adalah sekumpulan kaidah bagi perilaku yang diterima dalam satu zaman atau sekelompok orang, 2) moral adalah sekumpulan kaidah perilaku yang dianggap baik berdasarkan kelayakan bukan berdasarkan syarat, 3) moral adalah teori akal tentang kebaikan dan keburukan, menurut filsafat dan 4) tujuan-tujuan kehidupan yang mempunyai warna humanisme yang kental yang tercipta dengan adanya hubungan-hubungan sosial. Sementara itu, lebih lanjut dikemukakan meskipun dalam perkembangan moral kemampuan intelektual dan kemampuan memproses masukan ikut menentukan perkembangan itu, perilaku yang diwarnai dimensi moral pada diri seseorang memegang peranan penting. Dikatakan bahwa perkembangan moral berkorelasi dengan kehidupan individu dalam kelompok tertentu. Jadi , akhlak adalah secara keseluruhan kebiasaan manusia yang berasal dalam diri yang didorong keinginan secara sadar dan dicerminkan dalam perbuatan yang baik. Akhlak merupakan pondasi yang kokoh bagi terciptanya hubungan baik antara al-Kholiq sebagai pencipta dan manusia sebagai ciptaan-Nya. ${ }^{17}$

Pendidikan Akhlaq yang dilaksanakan Masjid Cheng Ho Surabaya dan Jember meliputi pendidikan tasawuf dan kajian remaja. pendidikan Tasawuf yang dilaksanakan untuk masyarakat umum baik remaja atau orang dewasa. Sedangkan kajian remaja dilaksanankan

\footnotetext{
${ }^{17}$ Halim, Ali Abdul. Akhlak Mulia terjemah Abdul Mayyie Al Kattani, (Jakarta: Gema Insani.2004)
} 
untuk remaja yang kebanyakan adalah pelajar untuk memperbaiki akhlak mereka baik akhlaq terhadap orang tua, guru dan juga akhlaq dalam berteman.

\section{KESIMPULAN}

Strategi yang dijalankan Masjid Cheng Ho Surabaya dan Jember adalah dengan menjalankan program pendidikan Al-Qur'an, Hadist, Aqidah dan Akhlaq. Untuk itu Masjid Cheng Ho tergolong sebuah Majlis Taklim Yang mempunyai kurikulum sesuai dengan PP Nomor 55 Tahun 2007 tentang Pendidikan Agama dan Pendidikan Keagamaan yang berbunyi "Majelis Taklim memiliki Kurikulum yang bersifat terbuka dengan mengacu pada pemahaman terhadap Al-Qur'an dan Hadits sebagai dasar untuk meningkatkan keimanan dan ketakwaan kepada Allah SWT, serta akhlak mulia"

\section{DAFTAR PUSTAKA}

Agama, D. (2010). Alquran dan Terjemahannya. Jakarta: Lajnah Pentashih Alquran.

Al-Qaththan, S. M. (2012). Pengantar Studi Ilmu Hadits. Pustaka Al Kautsar. Daulay, H.P. 2007. Sejarah Pertumbuhan dan Pembaruan Pendidikan Islam Di Indonesia. Jakarta: Kencana

Dhofier, Z. (2014). The Pesantren Tradition: A Study of the Role of the Kyai in the Maintenance of the Traditional Ideology of Islam in Java.

Halim, Ali Abdul. 2004. Akhlak Mulia terjemah Abdul Mayyie Al Kattani, Jakarta: Gema Insani

Hasan, M.T. (2000) Dinamika Kehidupan Religius. Jakarta: Listafariska Putra

Nata Abuddin. (2010) Sejarah Pendidikan Islam. Jakarta:Fakultas Ilmu Tarbiyah dan Keguruan)

Nomor, P. P. R. I. (55). Tahun 2007 tentang Pendidikan Agama dan Pendidikan Keagamaan. Jakarta: Kemenag.

PP Nomor 55 Tahun 2007 tentang Pendidikan Agama dan Pendidikan Keagamaan 
66 ... Potret Masyarakat Multikultural di Indonesia

Strategi Masjid Cheng Ho Dalam Meningkatkan Pendidikan Keagamaan Muslim

Tionghoa di Surabaya dan Jember

Semiawan, Conny. 1997. Perspektif Pendidikan Anak Berbakat, Jakarta, PT Gramedia.

Tabrani, Z. A. (2014). Menelusuri Metode Pendidikan dalam Al-Quran dengan Pendekatan Tafsir Maudhui. Serambi Tarbawi, 2(1). 